\title{
Use of Food Wastes for the Production of Lactic Silage
}

\author{
Ricardo Murray Martínez*, Pedro Cerezal Mezquita, Paulina Bermúdez and Richard \\ Bugueño Muñoz \\ Departamento de Alimentos; Facultad de Recursos Del Mar; Universidad de Antofagasta; Av. Universidad de \\ Antofagasta 02800; Casilla 170; Antofagasta - Chile
}

\begin{abstract}
The goal of the present work was to produce lactic silage from food wastes. A factorial $2^{3}$ experimental design was applied using the following factors and levels: yogurt inoculum concentration (1 and 15\%), sucrose (2 and 15\%) and temperature $\left(22\right.$ and $\left.35^{\circ} \mathrm{C}\right)$ and as response variable, the soluble nitrogen content $(S N C)$ at the end of the fermentation was considered. The best SNC output was for the treatment with $1 \%$ of inoculum, $2 \%$ of sucrose and temperature of $22^{\circ} \mathrm{C}$. The increase of SNC with regards to its initial content, from $0.17 \%$ to $1.67 \%$ for protein contents $(P C) \leq 5 \%$ corresponded to $882 \%$ and from $0.65 \%$ to $2.36 \%$ for $P C>5 \%$ represented $263 \%$. It was possible to produce a lactic silage and keep it stable for up to 30 days, which was enough storage time before being sent to a drying process for future use in animal feeding or compost.
\end{abstract}

Key words: food waste, lactic silage, lactic fermentation, institutional feeding

\section{INTRODUCTION}

In recent times, there has been great emphasis on the recovery, recycling and reconditioning of food waste, particularly from the fresh and processed food. Efforts have been made to use their wastes, effluents, residues and byproducts for the production of value added products (Laufenberg et al. 2003).

Organic wastes include animal manure, crop reminders and food processing wastes, municipal biosolids and wastes from some industries. They are typically byproducts of the field as well as of municipalities enterprises or industrial activities. They are called "wastes" for not being the primary products. These can be used for fertilizer, ground restorer, energy resource (heat, liquid fuels, electricity) and the production of chemicals (organic volatile acids, ammonium products, alcohols) (Westerman and Bicudo 2005).
Ensilage is defined as a semi-liquid or paste product, obtained from the residues of "eating waste" or ready-to-serve meals, or food waste (fishery industry, complete fishes or crustaceans or its ineligible parts for human consumption: head, tails, bones, skin, scales or viscera) by the action of the proteolytic enzymes that they contain. Its production is very easy; costs are quite low and it could be an ingredient of alimentary rations for the animals (González and Marín 2005; Ferraz de Arruda et al. 2007). There are two methods of ensiling: the chemical, which uses inorganic and/or organic acids, and the biological, which could be microbiological (use of microbial cultivations) or enzymatic (use of proteolytic enzymes) (Cira et al. 2002a, b; González and Marín 2005). The lactic fermentation has been proposed as one alternative for the stabilization of wastes since it offers advantages, mainly related to the low cost of investment, important in places

*Author for correspondence: rmurray@uantof.cl 
where there is no good infrastructure and an integral use of wastes is required, separating the products of high commercial value as chitin, pigments, proteins and lipids (Cira et al. 2002a, b). Ensiling is characterized as primarily a lactic acid fermentation process. During the initial stage of fermentation, excess oxygen is consumed, producing an anaerobic environment. During the second stage, from one day to three weeks, soluble carbohydrates are converted to lactic and acetic acid, ethanol, mannitol, acetaldehyde, and carbon dioxide by anaerobic bacteria (Roberts 1995). This period is characterized by a significant decrease in $\mathrm{pH}$. After three weeks, significant acetic and lactic acid accumulation result in $\mathrm{pH}$ declining to a level which inhibits further microbiological growth $(\mathrm{pH}<4.5)$ and the ensilage is considered to be stable (Murphy et al. 2007).

Food waste originating from the kitchens of the collective food service, contain a high concentration of biodegradable organic compounds and are predominant renewable sources in the municipal solid wastes (Wang and Nie 2001). Institutional canteens generate a significant amount of food waste which is disposed in the municipal sanitary landfills. This practice is carried out in the camps of mining companies workers, located far from the urban areas and usually established in the areas of Andean High Plain of II Region of Chile (Gobierno de Chile 2008). There is requirement to use these wastes for useful applications. An experiment about the use of catering waste, intended for cattle, was successfully carried out in four student residences at the University of Illinois (Hoelting 1994).

Food wastes, rich in nutrients, could be used in the compost for the cultivation of fast growing plants, mainly vegetables (Moravcová et al. 2004; Okine et al. 2005), food production for the animals or fish (Faid et al. 1997; Cira et al. 2002a, b; Plascencia et al. 2002; Vidoiti et al. 2002; Goddard and Perret 2005; Yang et al. 2006; Ferraz de Arruda et al. 2007), and generation of biodiesel (Canakci 2007). For the above reasons, it is necessary to develop an ensilage from of ready meals residues, by using the lactic fermentation (Bo et al. 2007) until obtaining the acidification that allows its conservation, with minimum losses of nutrients and small variability in its chemical composition (Díaz 2004), similar to the processes carried out to obtain the silage from of agricultural products (Aksu et al. 2004; Moravcová et al. 2004; Okine et al. 2005).

During the anaerobic treatment of lactic fermentation, some changes in the wastes take place caused by the decomposition of polymerized structures of the organic substances to simpler configurations, which could be immediately metabolized by the microorganisms, and used directly by the plants (Fassbender 1975; Winters et al. 2000). The main purpose of using the additives when making silage is to maintain a lactic acid fermentation that results in a well-preserved silage (McDonald et al. 1991) preventing the secondary fermentation and to decrease butyric acid production. The effectiveness of additives depends on the degree of preventing such fermentation in the silages (Aksu et al. 2004).

The objective of this work was to establish a technological process for obtaining an ensilage in paste form, inoculated with lactic strains, from the food waste of an institutional canteen.

\section{MATERIAL AND METHODS}

\section{Raw material used in preparation the silage}

The sample of food waste (ready meals waste) was obtained from the canteen in the city of Antofagasta. The waste was held in a plastic container of 60 L capacity with screw cap, previously conditioned for the incorporation of organic waste, and then shipped to the Industrial Processes Laboratory of Antofagasta University's Food Department, where foreign materials were separated, including the plastics, glass, paper, and cardboard, among others. Ready meals wastes (always with a time less than $24 \mathrm{~h}$ ) were drained, weighed and wet-milled using the warring blender for $3 \mathrm{~min}$ at the lowest speed, then pasteurized at $92 \pm 3{ }^{\circ} \mathrm{C}$ during 30 minutes and left to cool at room temperature $\left(\mathrm{T}=22 \pm 3{ }^{\circ} \mathrm{C}\right)$ for later use.

\section{Inspections carried out during fermentation}

The physical, chemical and microbiological analysis performed on the raw material, pasteurized paste of the organic waste, silage at different stages and the final product (final silage) were included the determination of moisture, protein, fat, fiber and ash; non-nitrogenous extract was calculated by difference (NNE), the latter being considered as an indirect measure of total carbohydrates present in the sample (AOAC 2000; ISP 1998a). The determination of chlorides was 
performed according to the procedure described by ISP (1998a), expressing the results in \% $\mathrm{NaCl}, \mathrm{pH}$ was measured by using a pH-meter model HI 8424 (Hanna Instrument), by means of the method described in AOAC (2000). The acidity was determined by acid-base titration using standard sodium hydroxide solution $(0.1 \quad \mathrm{~N})$ and phenolphthalein indicator and the results were expressed as \% of lactic acid (ISP 1998 a). The soluble nitrogen was measured by protein precipitation with trichloroacetic acid and subsequent determination of protein (Kjeldahl method) of the filtrate by AOAC (2000). Reducing sugars were measured by using the Lane-Eynon General Volumetric Method (Pearson 1998).

Microbiological Analysis: For this, decimal dilutions were made and duplicate Petri dishes were used for Plate Count for the total mesophilic aerobics of the samples; MRS (Man Rogosa Sharpe) medium was used for counting the lactobacilli.

\section{Inoculum preparation}

The inoculums was prepared by adding $2 \%$ stock culture of Lactobacillus bulgaricus and Streptococcus thermophilus in pasteurized fluid milk and incubating at $42 \pm 2{ }^{\circ} \mathrm{C}$ for $4 \mathrm{~h}$.

The yeast solution used as source of vitamin B, was prepared by adding dried yeast (10\%) in distilled water with acetic acid $(\mathrm{pH} 3.0)$. The solution was heated at $80 \pm 5^{\circ} \mathrm{C}$ for 4 minutes.

\section{Standardization of organic waste and flowchart of the silage process}

Fish silage was prepared following the report of Parin and Zugarramurdi (1997) and the concentrations of bacterial inoculum, sucrose and temperature were evaluated, taking increase of soluble nitrogen present in the organic waste as response variable. As first step, the organic paste was standardized with a $\mathrm{pH}$ range of 5.5 to 6.0 using $\mathrm{CaCO}_{3}$. The moisture was corrected to $76 \pm$ $1.0 \%$ for the tests under the same conditions. Samples of organic waste in the paste had variable protein levels, between 4.1 to $8.6 \%$, which led to the need of separating the wastes according to its protein content, taking as central point a $5 \%$ of protein, giving two sample types: those for which protein content was less than or equal to $5 \%$ (PC $\leq 5)$ and when the protein content was about $5 \%$ or higher $(\mathrm{PC}>5)$, thereby developing a design of silage in the paste (Fig. 1).

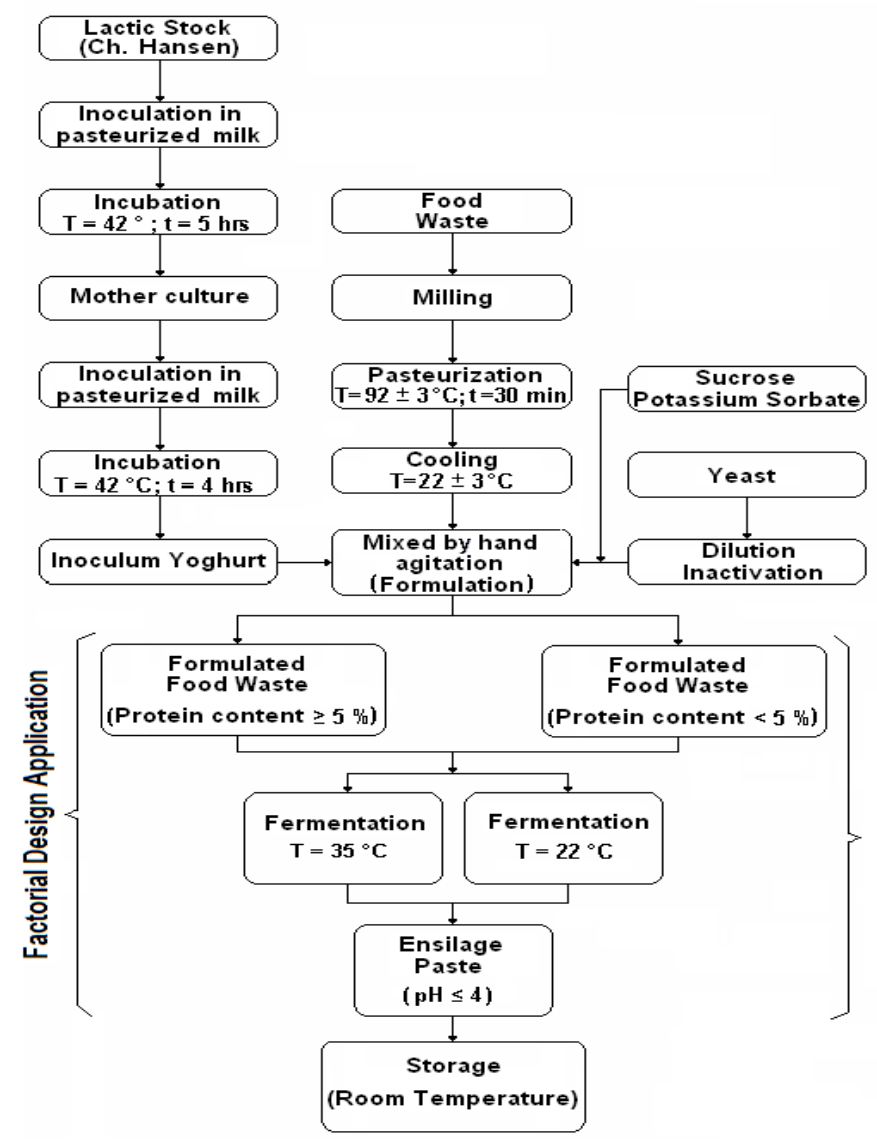

Figure 1 - Process diagram of ensilage from food waste. 


\section{Preliminary test to obtain silage}

In the preliminary tests, different concentrations of inoculum (5-14 \%) and sucrose (4-12\%) and different temperatures $\left(22-35{ }^{\circ} \mathrm{C}\right)$ were used according to the percentages used in investigations held in fish silage (Berenz 1997; Fredes 1996; Hervas 1992;). For each test, $2 \mathrm{~kg}$ of organic waste (paste) were weighed and also a $0.25 \%$ of potassium sorbate and $0.25 \%$ of yeast was added, and the fermentation was carried out as shown in the Figure 1, for organic wastes $\mathrm{PC} \leq 5$ and $\mathrm{PC}>$ 5.

\section{Statistical design in the formulation of the silage}

The results obtained on the ranges of concentrations and temperature used in the preliminary tests resulted in a mathematical model about the impact of the factors under study and the appropriate proportions for each of them.

The factorial design of three factors at 2 levels each $\left(2^{3}\right)$ was chosen (Gutiérrez and de la Vara 2003). Factor 1 was the inoculum concentration of a lactic strain $\left(\mathrm{X}_{1}\right)$ to be added (1 and $\left.15 \%\right)$, Factor 2 was the sucrose concentration $\left(\mathrm{X}_{2}\right)$ in the silage (2 and $15 \%$ ), and Factor 3 , was the incubation temperature $\left(\mathrm{X}_{3}\right)\left(22\right.$ and $\left.35^{\circ} \mathrm{C}\right)$. The response variable was the content of soluble nitrogen developed in the silage $(\bar{\gamma})$ when it reached the $\mathrm{pH}$ value of 4.0 , regardless of the time. For each of the different treatments, the experimental plan $(9 \mathrm{~kg}$ food waste paste with its additives, distributed in six plastic containers of 2 L capacity with screw cap) was implemented at random and the total design was done in duplicate.

Fermentation of the best formulation obtained from the mathematical model

After obtaining the result of the test with greater significance through the statistical analysis, both for $\mathrm{PC} \leq 5$ and $\mathrm{PC}>5$, fermentation was carried out at a larger scale $(20 \mathrm{~kg})$ of those experimental runs, which consisted in the preparation of silage, keeping the same processing conditions as shown in Figure 1.

\section{Parameters control in the fermentation process}

For the study on the fermentation progress of the silage for each test it was necessary to place the sealed containers designated as F1, F2, F3, F4 at $22 \pm 3{ }^{\circ} \mathrm{C}$ and the rest of the treatments, F5, F6, F7, F8 in incubator with thermoregulation (Memmert incubator model BE-300, Schwabach, Germany) at $35 \pm 3{ }^{\circ} \mathrm{C}$. The treatments were performed both for $\mathrm{PC} \leq 5$ and $\mathrm{PC}>5$.

All the samples were monitored on a daily basis for $\mathrm{pH}$ index, and the end of fermentation was assumed when each of them reached $\mathrm{pH}=4.0$, and the response variable referred to the content of soluble nitrogen was evaluated.

\section{RESULTS AND DISCUSSION}

\section{Obtaining the silage}

Table 1 shows the chemical composition of the two groups of residues used in the study before the fermentation process. The wastes $\mathrm{PC} \leq 5 \%$ and $\mathrm{PC}$ $>5 \%$ showed moisture contents in a range of 74 to $76 \%$ which was reported by Titterton (2000) from 65 to $75 \%$. Such percentages have been identified as suitable for obtaining a silage in optimal conditions from the plants and animal products.

Protein content in the wastes was an important factor to be considered and the contents agreed with those reported by Chedly and Lee (2000), Gutiérrez et al. (2003) and Juan et al. (2003).

Table1 - Proximal chemical composition of food waste before the fermentation process $(n=5)$.

\begin{tabular}{lcccc}
\hline \multirow{2}{*}{ Chemical Composition $\left(\mathbf{g} * \mathbf{1 0 0 g}^{-\mathbf{1}}\right)$} & \multicolumn{2}{c}{$\mathbf{P C} \leq \mathbf{5} \%$} & \multicolumn{2}{c}{$\mathbf{P C}>\mathbf{5} \%$} \\
\cline { 2 - 5 } & $\overline{\mathbf{x}}$ & $\mathbf{S}$ & $\overline{\mathbf{x}}$ & $\mathbf{S}$ \\
\hline Moisture & 75.9 & 2.5 & 74.8 & 1.5 \\
Crude Proteins & 4.4 & 0.3 & 6.8 & 1.1 \\
Crude Lipids & 9.5 & 1.8 & 9.1 & 0.5 \\
Ash & 0.9 & 0.2 & 1.1 & 0.5 \\
NNE* & 8.5 & 2.7 & 7.8 & 1.2 \\
Fiber & 0.8 & 0.3 & 0.4 & 0.2 \\
\hline
\end{tabular}

PC: Proteins content; $\overline{\mathbf{x}}$ Average values; S: Typical deviation; NNE: Non-nitrogenous extract by difference $(100-\Sigma$ Other components). 
Although no specific information on the physicochemical characteristics of organic wastes was found, studies conducted with fish scrap, Ottati et al. (1990) and Hervas (1992) obtained good results without interference of the lactic acid, with protein content up to around 19 to $20 \%$.

Therefore, having organic wastes containing protein not exceeding $7 \%$ (on wet basis), $4.4 \%$ for $\mathrm{PC} \leq 5 \%$ (18.26\% on dry basis) and $6.8 \%$ for PC > $5 \%(26.98 \%$ on dry basis) resulted a good fermentation process.

The carbohydrate content of $8.5 \%$ and $7.8 \%$ in PC $\leq 5 \%$ and $\mathrm{PC}>5 \%$, expressed as NNE on wet basis, respectively were acceptable percentages for silage processing, either as a fermentable substrate of immediate consumption or as insoluble carbohydrates by the lactic acid bacteria, which helped to preserve the silage (Oude 2000; Machin 2000).

Lipid content in the organic wastes $\mathrm{PC} \leq 5 \%$ and PC > 5\% with 9.5 and $9.1 \%$, respectively on wet basis, were four times higher than those reported by Bello (1997) who pointed out $2 \%$ as adequate, and above this value could be a risk of secondary processes such as oxidative rancidity in the fermentation and consequent loss of quality of the silage. Although the rancidity of ensilage was not measured, no signs of lipid damage were seen during the fermentation of 30 days.
Dry matter in the organic waste was 24.1 and $25.2 \%$ similar to the lower limit reported by Titterton (2000) who found that dry matter should be about 25 to $35 \%$ for producing good quality silage.

Chlorides content, expressed as sodium chloride of 1.35 and $1.62 \%$ for $\mathrm{PC} \leq 5 \%$ and $\mathrm{PC}>5 \%$, respectively, were within the range of values established, since the incorporation of common salt (sodium chloride) as well as $\mathrm{Ca}$ and $\mathrm{Mg}$ sources were always needed.

The best silage (for both groups of residues) according to the highest concentration of soluble nitrogen produced was as follows: $2.0 \%$ of sucrose, $1.0 \%$ of inoculums (w/w) of lactic acid bacteria strain and, an incubation temperature $22 \pm$ $3^{\circ} \mathrm{C}$. This experimental design yielded significant differences of the factors under study related to the response variable, soluble nitrogen. This formulation and fermentation temperature allowed obtaining the stable silage without any alterations up to 30 days of storage.

Table 2 presents the proximate chemical composition (moisture, proteins, fats, ashes, fibers and non-nitrogenous extract by difference) of the paste silage obtained from the final formulation (larger scale experiment), at the beginning and end of the 30 days of storage.

Table 2 - Proximal chemical composition of ensilage (\%) (wet basis) in the larger scale experiment 0 and 30 days (n $=5)$.

\begin{tabular}{|c|c|c|c|c|}
\hline \multirow{3}{*}{ Chemical Composition $\left(\mathrm{g} * 100 \mathrm{~g}^{-1}\right)$} & \multicolumn{4}{|c|}{ Days } \\
\hline & \multicolumn{2}{|c|}{ 0 } & \multicolumn{2}{|c|}{30} \\
\hline & $\overline{\mathbf{x}}$ & $\mathbf{S}$ & $\overline{\mathbf{x}}$ & $\mathrm{S}$ \\
\hline Moisture & 74.5 & 7.1 & 75.3 & 6.7 \\
\hline Crude Proteins & 4.3 & 0.3 & 3.9 & 0.2 \\
\hline Crude Lipids & 8.3 & 0.6 & 8.5 & 0.9 \\
\hline Ash & 0.9 & 0.1 & 0.9 & 0.1 \\
\hline NNE* & 11.7 & 1.4 & 10.8 & 1.9 \\
\hline Fiber & 0.3 & 0.0 & 0.3 & 0.0 \\
\hline
\end{tabular}

$\overline{\mathbf{x}}$ Average values; S: Typical deviation; NNE: Non-nitrogenous extract by differential (100 - $\Sigma$ Other components).

Evolution of soluble nitrogen content in the factorial design study at the pilot scale

Table 3 shows the values of soluble nitrogen at the end of the fermentation of the two groups of study, $\mathrm{PC} \leq 5 \%$ and $\mathrm{PC}>5 \%$. F8 runs in each experimental group exhibited the highest increase in the soluble nitrogen, $1.67 \%$ and $2.36 \%$ respectively, and $\mathrm{F} 3$ experimental runs showed the lowest percentages of soluble nitrogen, 0.57 and $1.20 \%$. The results of F8 experimental runs of PC $\leq 5 \%$ and $\mathrm{PC}>5 \%$ were the same as reported by Bello (1997) who found that maintaining the silage fermentation process with an increased incubation time and temperatures below the optimum for the bacterial growth resulted in the increased production of nitrogen compounds of low molecular weight such as peptides and amino acids due to the unfolding of the protein by the lactic acid bacteria. 
The increase in the content of soluble nitrogen increase from initial content of 0.17 to $1.67 \%$ for $\mathrm{PC} \leq 5$ corresponded to $882 \%$ and for PC $>5 \%$ from 0.65 to $2.36 \%$ which represented an increase of $263 \%$. The soluble nitrogen increases in the fermentation process were higher when the initial content in the organic waste was low. The residues with a high initial percentage of soluble nitrogen have a strong buffering capacity in the medium, causing the neutralization of acid production by the lactic acid bacteria in an efficient manner and the subsequent inhibition of the proteolytic capacity. The experimental runs with a higher increase of soluble nitrogen after the F8 for PC $\leq$ $5 \%$ and $\mathrm{PC}>5 \%$ were the $\mathrm{F} 7$ with $2.11 \%$ and $1.4 \%$ respectively, and corresponded to a increase of 724 and $225 \%$, respectively.

Table 3 - Factorial design matrix $2^{3}$ in the realization of experiment to pilot scale.

\begin{tabular}{|c|c|c|c|c|c|c|}
\hline \multirow{4}{*}{ Formulations } & & \multicolumn{3}{|c|}{ Factors / Levels } & \multirow{2}{*}{\multicolumn{2}{|c|}{$\begin{array}{c}\text { Response variable } \\
\text { Soluble nitrogen }(\%)\end{array}$}} \\
\hline & & Inoculum (\%) & Sucrose $(\%)$ & Temperature $\left({ }^{\circ} \mathrm{C}\right)$ & & \\
\hline & & \multirow{2}{*}{$\left(\mathbf{X}_{1}\right)$} & \multirow{2}{*}{$\left(\mathbf{X}_{2}\right)$} & \multirow{2}{*}{$\left(\mathbf{X}_{3}\right)$} & \multicolumn{2}{|c|}{$(\bar{Y})$} \\
\hline & & & & & $\mathrm{PC}<5 \%$ & $\mathrm{PC}>5 \%$ \\
\hline F-1 & \multirow{8}{*}{$D=$} & $1(15)$ & $1(15)$ & $1(35 \pm 3)$ & 1.10 & 1.89 \\
\hline $\mathrm{F}-2$ & & 1 & $-1(2)$ & 1 & 0.63 & 1.57 \\
\hline $\mathrm{F}-3$ & & $-1(1)$ & 1 & 1 & 0.57 & 1.20 \\
\hline F-4 & & -1 & -1 & 1 & 0.70 & 1.47 \\
\hline F-5 & & 1 & 1 & $-1(22 \pm 3)$ & 1.20 & 1.93 \\
\hline F-6 & & 1 & -1 & -1 & 0.78 & 1.65 \\
\hline F-7 & & -1 & 1 & -1 & 1.40 & 2.11 \\
\hline F-8 & & -1 & -1 & -1 & 1.67 & 2.36 \\
\hline
\end{tabular}

D: Factorial matrix expression; PC: Protein content; $\bar{Y}:$ Average values of two determinations.

Mathematical model to maximize the response variable (soluble nitrogen) $(\mathbf{Y})$

According to the analysis of variance (Tables 4 and 5) and the interpretations of the Pareto charts (Fig. $2 a$ and $2 b$ ), the $X_{1}, X_{2}$, and $X_{3}$ showed no significant differences $(p<0.05)$ on the response variable, $\mathrm{Y}$, in both the models for the $\mathrm{X}_{1}$ and $\mathrm{X}_{2}$ factors and $X_{2} X_{3}$ interactions, suggesting that the mathematical model represented only a function of $X_{3}$ factor and the $X_{1} X_{2}$ and $X_{1} X_{3}$ interactions.

These equations are shown in each of the response surface plots using the experimental design (Fig. $3 \mathrm{a}$ and $3 \mathrm{~b}$ ). Both the equations were similar in their structures (coefficients and factors), regardless of protein content and the temperature range.

Table 4 - Summary of the analysis of variance to $\mathrm{PC} \leq 5 \%$.

\begin{tabular}{lccccc}
\hline Effect & Sum of squares & d.f. & Mean quare & $\boldsymbol{F}$-ratio & $\boldsymbol{p}$-value \\
\hline $\mathrm{X}_{1}$ : Inoculum & 0.04961 & 1 & 0.04961 & 49.00 & 0.0903 \\
$\mathrm{X}_{2}$ : Sucrose & 0.03001 & 1 & 0.03001 & 29.64 & 0.1156 \\
$\mathrm{X}_{3}:$ Temperature & 0.52531 & 1 & 0.52531 & 518.83 & $* \mathbf{0 . 0 2 7 9}$ \\
$\mathrm{X}_{1} \mathrm{X}_{2}$ & 0.20801 & 1 & 0.20801 & 205.44 & $* \mathbf{0 . 0 4 4 3}$ \\
$\mathrm{X}_{1} \mathrm{X}_{3}$ & 0.30031 & 1 & 0.30031 & 296.60 & $* \mathbf{0 . 0 3 6 9}$ \\
$\mathrm{X}_{2} \mathrm{X}_{3}$ & 0.00451 & 1 & 0.00451 & 4.46 & 0.2816 \\
Error (total) & 0.00101 & 1 & 0.00101 & & \\
Total & 1.11879 & 7 & & & \\
\hline (*) statistically significant; $\mathrm{R}^{2}=0.9991 ;$ Standard error of estimate $=0.032$ & & & \\
$\mathrm{R}^{2}$ (adjusted for d.f.; degrees of freedom) $=0.9939$ &
\end{tabular}

Table 5 - Summary of the analysis of variance to PC $>5 \%$.

\begin{tabular}{lccccc}
\hline Effect & Sum of squares & d.f. & Mean Square & F-ratio & p-value \\
\hline $\mathrm{X}_{1}:$ Inoculum & 0.00125 & 1 & 0.00125 & 2.78 & 0.3440 \\
$\mathrm{X}_{2}:$ Sucrose & 0.00080 & 1 & 0.00080 & 1.78 & 0.4097 \\
$\mathrm{X}_{3}:$ Temperature & 0.46080 & 1 & 0.46080 & 1024.00 & $* \mathbf{0 . 0 1 9 9}$ \\
$\mathrm{X}_{1} \mathrm{X}_{2}$ & 0.15680 & 1 & 0.15680 & 348.44 & $* \mathbf{0 . 0 3 4 1}$ \\
$\mathrm{X}_{1} \mathrm{X}_{3}$ & 0.35280 & 1 & 0.35280 & 784.00 & $* \mathbf{0 . 0 2 2 7}$ \\
$\mathrm{X}_{2} \mathrm{X}_{3}$ & 0.00005 & 1 & 0.00005 & 0.11 & 0.7952 \\
Error (total) & 0.00045 & 1 & 0.00045 & & \\
Total & 0.97295 & 7 & & & \\
\hline
\end{tabular}

$(*)=$ statistically significant; $\mathrm{R}^{2}=0.9995 ;$ Standard error of estimate $=0.021$

$\mathrm{R}^{2}$ (adjusted for d.f.; degrees of freedom) $=0.9968$. 


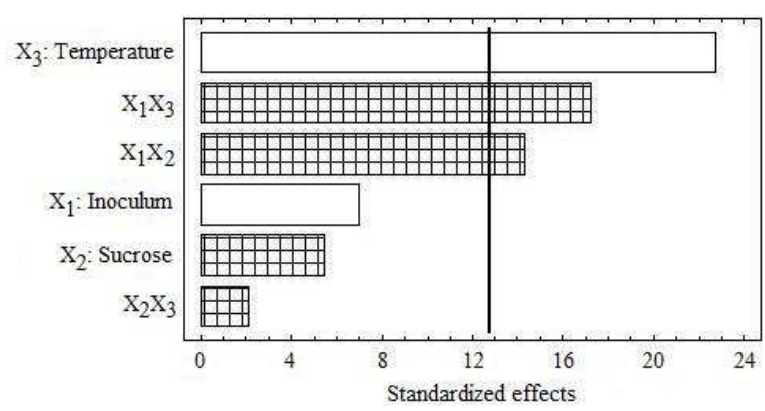

(a)

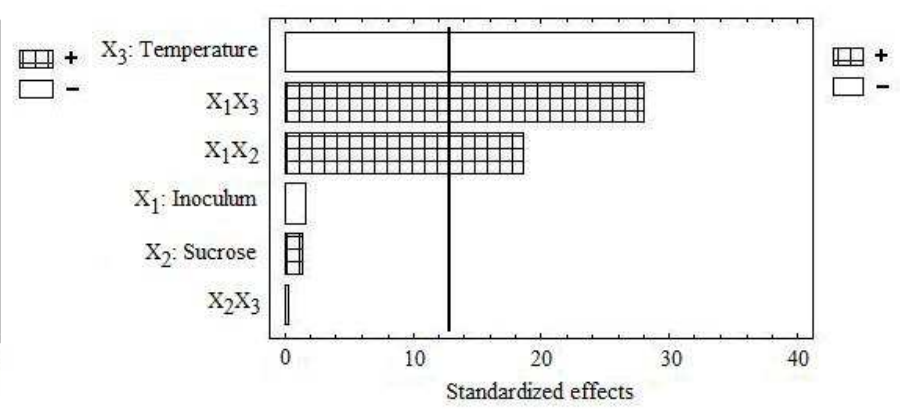

(b)

Figure 2 - Pareto chart for the standardized effects in the Factorial-Design $2^{3}$ for (a) $\mathrm{PC} \leq 5 \%$ and (b) $\mathrm{PC}>5 \%$, including three-factor and its interactions. The vertical line indicates the statistical significance bond for the effects.

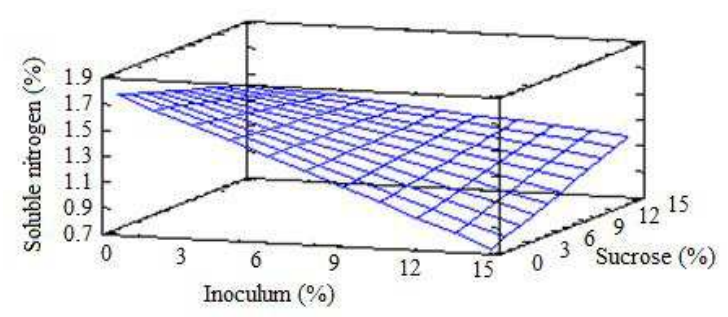

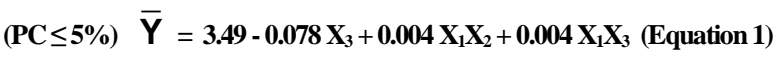

(a)

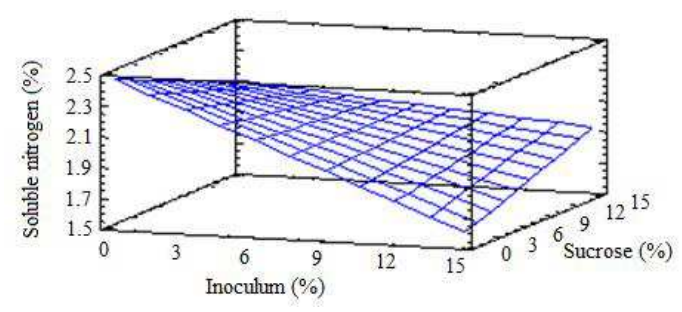

$(\mathrm{PC}>5 \%) \overline{\mathrm{Y}}=4.10-0.074 \mathrm{X}_{3}+0.003 \mathrm{X}_{1} \mathrm{X}_{2}+0.005 \mathrm{X}_{1} \mathrm{X}_{3}$ (Equation 2)

(b)

Figure 3 - Response surface analysis to ensilage with fitted mathematical model: a) content protein $(\mathrm{PC}) \leq 5 \%\left(\mathrm{~T}=22^{\circ} \mathrm{C}\right)$; and b) content protein $(\mathrm{PC})>5 \%\left(\mathrm{~T}=22^{\circ} \mathrm{C}\right)$.

\section{pH Evolution during the experiment}

The $\mathrm{pH}$ results obtained in the fermentation control of organic wastes classified as $\mathrm{PC} \leq 5$ are shown in Figure 4a. Evidently the formulations F2, $\mathrm{F} 3, \mathrm{~F} 4$ reached $\mathrm{pH} 4.0$ two days after incubation at $35{ }^{\circ} \mathrm{C}$, while the $\mathrm{F} 1$ formulation achieved the $\mathrm{pH}$ 4.0 after three days of incubation at the same temperature.

On the other hand, formulations incubated at $\mathrm{T}=$ $22 \pm 3{ }^{\circ} \mathrm{C}$ (Fig. 4b), F7 and F8, showed a slower $\mathrm{pH}$ decrease, falling to reach $\mathrm{pH} 4.0$ in six days and formulations F5 and F6 in five days, respectively.

Therefore, the end of the fermentative process was faster in the formulations incubated at $35{ }^{\circ} \mathrm{C}$ lasting from 2 to 3 days (F1, F2, F3, F4), compared with those incubated at $22{ }^{\circ} \mathrm{C}$ which ended the fermentation process in six days (F5, F6, F7, F8).
Figure $4 \mathrm{c}$ showed the results obtained on organic waste with a percentage of $5 \%$ protein $(\mathrm{PC}>5 \%)$, pointing the end of the fermentation process for the formulations incubated at $\mathrm{T}=35 \pm 3{ }^{\circ} \mathrm{C}(\mathrm{F} 2$, F3 and F4) after three days and for formulation F1 after four days, while the formulations incubated at $\mathrm{T}=22 \pm 3{ }^{\circ} \mathrm{C}$ (Fig. 4d), F5, F6, F7, reached pH 4.0 after six days and formulation F8 after eight days. The end of the fermentative process reached in more time for this type of waste (PC $>5 \%$ ) being around 3 to 4 days for the formulations incubated at $\mathrm{T}=35 \pm 3{ }^{\circ} \mathrm{C}$ and eight days for the formulations at $\mathrm{T}=22 \pm 3{ }^{\circ} \mathrm{C}$. Figures $4 \mathrm{a}$ to $4 \mathrm{~d}$ showed that in spite of showing the same trend, the difference was of two days for $\mathrm{T}=22 \pm 3^{\circ} \mathrm{C}$ and one day for $\mathrm{T}=35 \pm 3^{\circ} \mathrm{C}$, which was due to the buffering capacity present in the medium, compared to low protein content wastes (Kunz 1986; Hervas 1992; Bello,1997). It was also be 
noted that the fermentation time was within the ranges of 3 to 10 days, similar as indicated by Lay et al. (2003). Although in both the experimental designs, the time factor was not directly considered, the response variable was conditional on it through the $\mathrm{pH}$ (Equations 1 and 2 in Fig. 3a y $3 b)$.

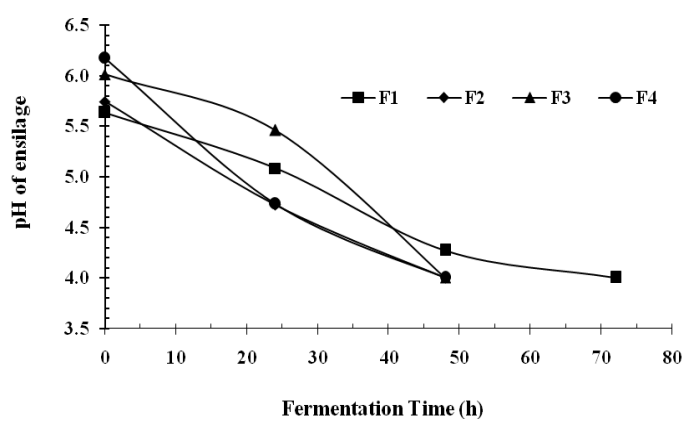

(a)

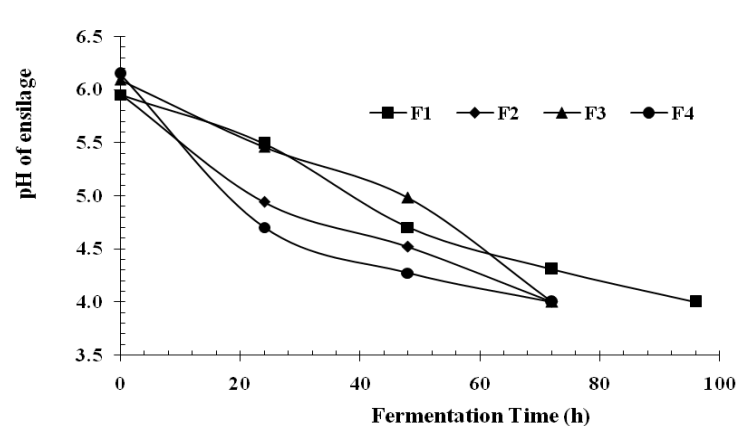

(c)
The $\mathrm{pH}$ results obtained in the fermentation process led to the conclusion that both the wastes $\mathrm{PC} \leq 5 \%$ and $\mathrm{PC}>5 \%$ followed the trend reported by Kung (2001), who put $\mathrm{pH}$ values between 3.7 and 4.2 for the fodder silage.

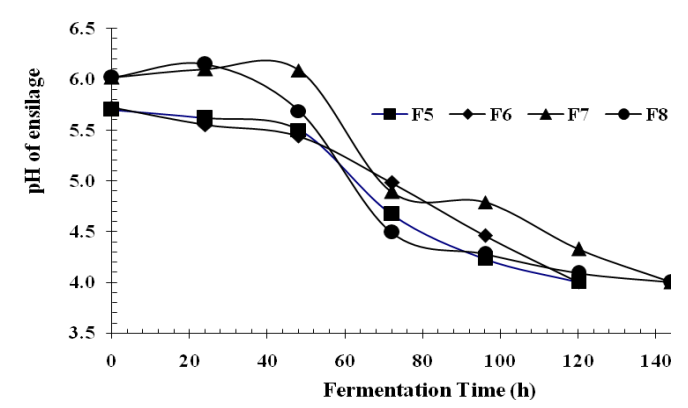

(b)

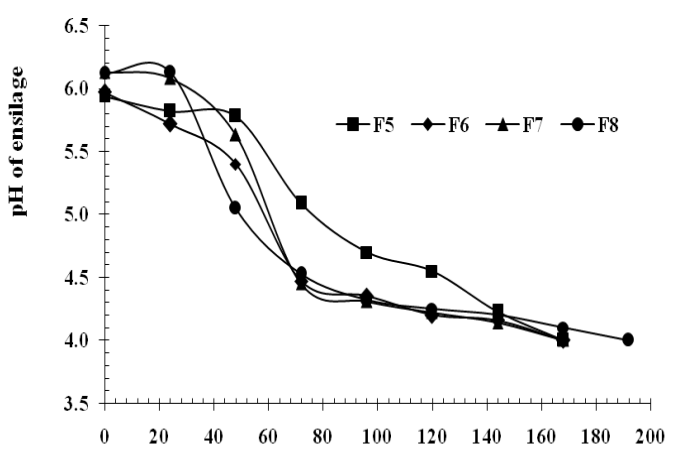

(d) Termentation Time (h)

Figure 4 - pH variation versus Fermentation Time. (a) [F1-F4 Formulations with protein content (PC) $\leq 5 \%$ and $\mathrm{T}=35^{\circ} \mathrm{C}$; (b) [F5-F8 Formulations with protein content (PC) $\leq 5 \%$ and $\left.\mathrm{T}=22{ }^{\circ} \mathrm{C}\right]$; (c) $[\mathrm{F} 1-\mathrm{F} 4$ Formulations with protein content $(\mathrm{PC})>5 \%$ and $\mathrm{T}=35$ $\left.{ }^{\circ} \mathrm{C}\right]$; (d) [F5-F8 Formulations with protein content $(\mathrm{PC})>5 \%$ and $\left.\mathrm{T}=22{ }^{\circ} \mathrm{C}\right]$

\section{Evaluation of the optimized formulation}

According to the two fitted mathematical models obtained after the completion of ANOVA for each working area (factors and levels) in PC $\leq 5 \%$ and PC $>5 \%$, it could be concluded that the F8 formulation had a higher performance in both of them, as it delivered the highest concentration of soluble nitrogen. For this reason, only one wastes was used further and this choice was based on the higher values of soluble nitrogen $\mathrm{PC} \leq 5 \%$.

Figure 5 shows the $\mathrm{pH}$ and lactic acid (LA) behaviors setting off the $\mathrm{pH}$ decrease and lactic acid increase over the time. The $\mathrm{pH}$ decreased until the desired values in the first six days of incubation. On the first day, the rate of decrease of $\mathrm{pH}$ (initial value 5.78) and increased LA (initial content of 0.30) was slow to rise to a value of $\mathrm{pH}$ $=4.0$ and $\mathrm{LA}=1.4 \%$, representing an increase of 4.7 times at the end of fermentation.

There were differences in the fermented residues for the ratio of acid produced and the final $\mathrm{pH}$ obtained in fish silage to get a final $\mathrm{pH}$ of 3.9. The LA content exceeded 5.8\% (Ottati et al. 1990), about 0.73 to $1.75 \%$ in viscera residue (Vignolo et al. 2005) and below $2 \%$ in fodder silage (Betancourt et al. 2003). The difference between the decrease in the $\mathrm{pH}$ and lactic acid production in the various studied silage wastes was due to the different buffer capacity presented by the wastes, provided by the input of soluble nitrogen in the raw materials (Gutiérrez et al. 2003). 


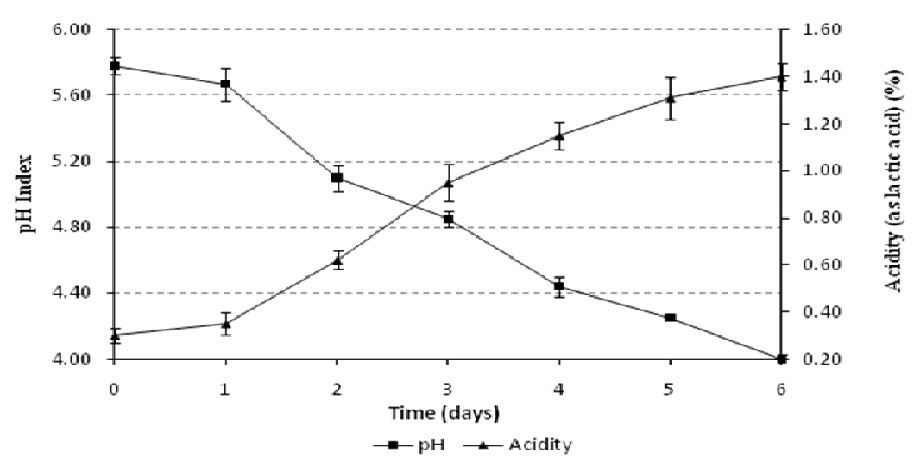

Figure 5 - pH and acidity variation (Optimized formulation).

During the fermentation of organic wastes, the production of lactic acid by the yogurt lactic acid bacteria kept a continuous rise over six days, reaching $1.4 \%$ of acidity expressed as lactic acid, which resulted in a $\mathrm{pH}=4.0$, indicating the end of the fermentative process.

\section{Decrease of reducing sugars}

Figure 6 shows the variation of reducing sugars during the fermentation. Organic waste without any treatment showed a $0.34 \%$ of reducing sugars in the initial stages and increased rapidly to $2.1 \%$ at the beginning of fermentation (time $=0$ ) by the addition of sucrose in the presence of acid, which was hydrolyzed to reducing sugars.

Throughout the fermentation process, the fermentable substrate as sole source of energy for the growth of L. bulgaricus and S. thermophilus, decreased as shown in Figure 5, confirming the growth of the bacteria supported by the increased acidity of the system.

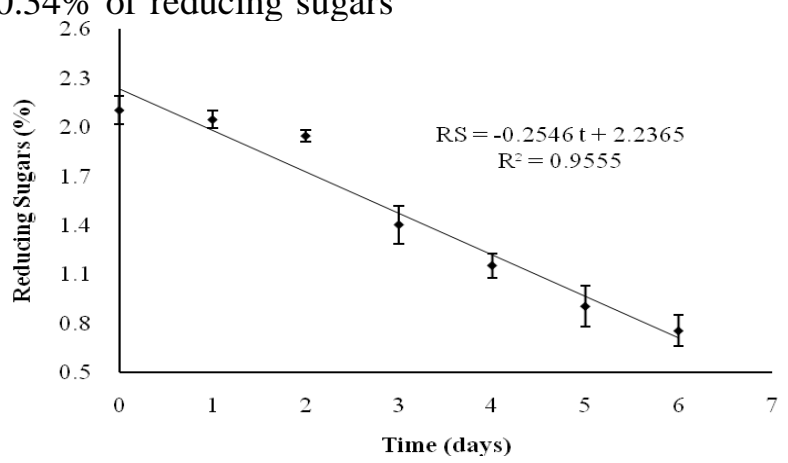

Figure 6 - Reducing sugars variation (Optimized formulation).

Reduction of reducing sugars in the first two days was only $7.14 \%$, but there was a drop of $57.14 \%$ from here until the $5^{\text {th }}$ day, which indicated the bacterial growth in its full exponential phase. In the course of the $5^{\text {th }}$ and $6^{\text {th }}$ day, the speed decreased and reduction was $16.67 \%$, which could be due to a semi-stationary phase behavior of lactic acid bacteria.

\section{Increase of soluble nitrogen}

Figure 7 shows the soluble nitrogen increase which was seen on the 1st day with a strong growth of 4.8 times compared to the initial concentration (from 0.28 to $1.35 \%$ ) represented by the linear behavior. Throughout the next five days, it continued with a slowly progressive increase of no more than $20 \%$. This increase might be due to the hydrolyzing capacity of the Lactobacillus, which took part in the degradation of the proteins by the proteolytic enzymes. This relationship between the $\mathrm{pH}$ decrease and soluble nitrogen increase (Fig. 7) showed the proteolytic enzymes activity, increasing the shock absorbing power of wastes and slightly reducing the $\mathrm{pH}$ to acidic range, which caused a self-control system by the lactic acid bacteria, which produced more lactic acid and did not alter the $\mathrm{pH}$ drastically (Ottati et al. 1990). 


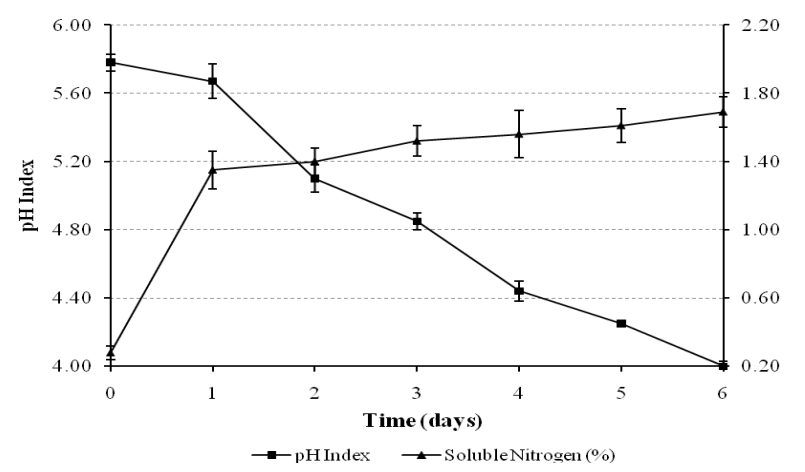

Figure 7 - Soluble nitrogen vs $\mathrm{pH}$ variation (Optimized formulation).

Figure 8 showed that on the 6th day of incubation, a $38 \%$ of the total protein was in form of soluble nitrogen showing that the increase was less marked than what was stated by Ottati et al. (1990) whose experiments were based on fish waste and about the $60 \%$ of the total protein was found in form of soluble nitrogen.

These differences were due to own characteristics of the waste used in the ensiling process.

\section{Evaluation of silage on day 30 of storage}

The evaluation of the stored ensilage was also taken into consideration due to the feasibility of finding better soluble nitrogen results through time and to verify if the conservation conditions were kept. For this reason, after the end of fermentation, when arriving at $\mathrm{pH}=4.0$, no action was taken to stop the activity by the lactic bacteria. Thus, after 30 days of storage, the silage $\mathrm{pH}$ at $\mathrm{T}=22 \pm 3^{\circ} \mathrm{C}$ presented a further decrease to 3.45 , reflecting a positive microbial activity, continuing the production of lactic acid to $2.12 \%$. These features were also present in the fodder silage and offal waste after six months (Ottati et al. 1990).

The lactic acid bacteria used the reducing sugars, achieving a concentration from $0.54 \%$ after 30 days of storage, which indicated that there were still sufficient energy reserves to be used by the bacteria for their survival (Pizardi 1999).

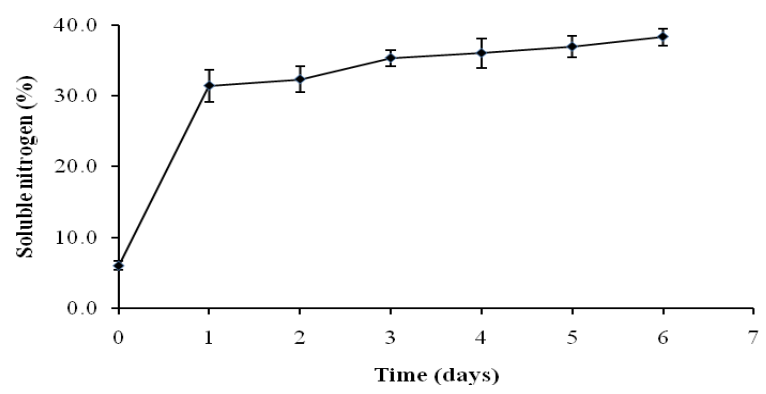

Figure 8 - Soluble nitrogen in the protein (Optimized formulation).

\section{CONCLUSION}

It was possible to develop a lactic ensilage from the food wastes generated in the canteens in a short period of time by fermentation (not more than six days) at room temperature. After 30 days of storage (kept in the closed containers with screw cap), the silage $\mathrm{pH}$ in the ambient conditions of $\mathrm{T}=22 \pm 3{ }^{\circ} \mathrm{C}$, presented a further decrease to 3.45 , reflecting a positive microbial activity, continuing the production of lactic acid to $2.12 \%$. This storage time was more than enough before being sent for a drying process for future use in the animal feed or as compost.

\section{ACKNOWLEDGEMENTS}

The authors are thankful to the enterprise "Minera Escondida Ltda", Antofagasta - Chile, for the support given to this investigation financing the Research Project under grant numbers 4524 of the Antofagasta University. 


\section{REFERENCES}

Aksu T, Baytok E, Bolat D. Effects of a bacterial silage inoculant on corn silage fermentation and nutrient digestibility. Small Ruminant Res. 2004;55(1): 249252.

AOAC. Official Methods of Analysis $17^{\text {th }}$ ed. Washington DC: Association of Official Analytical Chemists; 2000.

Bello R. Experiencia con Ensilado de Pescado en Venezuela. En: Figueroa V, Sánchez M. Editores. Tratamiento y utilización de residuos de origen animal, pesquero y alimenticio en la alimentación animal. La Habana. Estudio FAO Producción y Sanidad Animal. 1997; $\mathrm{N}^{\circ}$ 134; p 1-14.

Berenz Z. Utilización del ensilado de residuos de pescado en pollos. En: Figueroa V, Sánchez M. Editores. Tratamiento y utilización de residuos de origen animal, pesquero y alimenticio en la alimentación animal. La Habana. Estudio FAO Producción y Sanidad Animal. 1997; N ${ }^{\circ} 134$; p 1528.

Betancourt M, Bravo J, Caraballo A, Fuenmayor A, Gonzalez I, Martinez M, et al. Efecto de la melaza, acido fórmico y tiempo de fermentación sobre el contenido de proteína cruda y nitrógeno amoniacal en silaje de Leucaena leucocephala. Zootecnia Trop. 2003; 21(3): 290-6.

Bo Z, Wei-min C, Pin-jing H. Influence of lactic acid on the two-phase anaerobic digestion of kitchen wastes. J Environ Sci. 2007; 19(2): 244-9.

Canakci M. The potential of restaurant waste lipids as biodiesel feedstocks. Bioresource Technol. 2007; 98(1): 183-190.

Chedly K, Lee S. Uso del ensilaje en el trópico privilegiando opciones para pequeños campesinos: Ensilaje de subproductos agrícolas como opción para los pequeños campesinos. En: Memorias de la Conferencia Electrónica de la FAO sobre el Ensilaje en los Trópicos. Estudios de la FAO Producción y Protección Vegetal. Roma Italia. 2000; 161, p 87 110.

Cira LA, Huerta S, Shirai K. Fermentación láctica de cabezas de camarón (Penaeus sp) en un reactor de fermentación sólida. Rev Mex Ing Quím. 2002a; 1 (12): 45-8.

Cira LA, Huerta S, Hall GM, Shirai K. Pilot scale lactic acid fermentation of shrimp wastes for chitin recovery. Process Biochem. 2002b; 37(12): 13591366.

Diaz H. Efecto de la suplementación con ensilaje de residuos de una planta procesadora de Tilapia (Oreochromis niloticus) sobre el consumo voluntario y la digestibilidad de nutrientes de henos de gramíneas y leguminosas tropicales. [Master Thesis]. Mayagüez, Puerto Rico, Universidad de Mayagüez; 2004.
Faid M, Zouiten A, Elmarrakchi A, Achkari-Begdouri A. Biotransformation of fish waste into a stable feed ingredient. Food Chem. 1997; 60(1): 13-18.

Fassbender H. Química de suelos com énfasis en Suelos de América Latina. $1^{\text {st }}$ ed. Turrialba: Instituto Interamericano de Ciencias Agrícolas; 1975.

Ferraz de Arruda L, Borghesi R, Oetterer M. Use of Fish Waste as Silage - A Review. Braz Arch Biol Techn. 2007; 50(5): 879-886.

Fredes F. (1996). Deshidratación de Ensilado de Pescado Obtenido por Fermentación Láctica. [Undergraduate Thesis]. Antofagasta, Chile: Universidad de Antofagasta; 1996.

Gobierno de Chile. Mapa Minero. Ministerio de Minería. Gobierno de Chile. 2008, Oct. 12 [updated 2010 May 5; cited 2011 April 03] Available from: http://www.gobiernodechile.cl/media/2010/05/MINE RIA.pdf

Goddard JS, Perret JSM. Co-drying fish silage for use in aquafeeds. Anim Feed Sci Tech. 2005; 118(3-4): 337-342.

González D, Marín M. Obtención de ensilados biológicos a partir de los desechos del procesamiento de sardinas. Rev Cient - Fac Cien V. 2005; 15(6): 560-7.

Gutiérrez F, Rojas-Bourrillón A, Dormond H, Poore M, Wing R. Características nutricionales y fermentativas de mezclas ensiladas de desechos de piñas y avícolas. Agron Costarric. 2003; 27(1): 79-89.

Gutiérrez H. de la Vara R. Análisis y Diseño de Experimentos. $1^{\text {st }}$ ed. México D.F.: McGraw-Hill Interamericana; 2003.

Hervas C. Obtención de un Alimento para consumo animal a partir de Sardina Española (Sardinops sagax) mediante fermentación láctica. [Undergraduate Thesis]. Antofagasta, Chile: Universidad de Antofagasta; 1992.

Hoelting FB, Walker PM. Illinois State University to recycle dining center food and paper wastes into cattle feed. Bioresource Technol. 1994; 49(1): 89-92.

ISP. Métodos de análisis fisicoquímicos de alimentos, aguas y suelos. $1^{\text {st }}$ ed. Santiago de Chile: Andros Ltda; 1998a.

ISP. Técnicas Microbiológicas para alimentos y Aguas. 1st ed. Santiago de Chile: Andros Ltda; 1998b.

Juan NA, Romero LA, Bruno OA. Conservación del forraje de alfalfa. En: INTA CR. editor. La Alfalfa en la Argentina. Cuyo: INTA CR.; 1995. p 173-192.

Kunz B. Cultivo de Microorganismos para la Producción de Alimentos: Obtención, Aplicaciones e Investigación. $1^{\text {st }}$ ed. Zaragoza: Edit. Acribia S.A.; 1986.

Kung L. Silage Fermentation and Aditives. In: Directfed Microbial, Enzyme and Forage Additive Compendium. Miller Publishing Co. Minnetonka. 2001. p 1-18. 
Lay JJ, Fan KS, Chang J, Ku CH. Influence of chemical nature of organic wastes on their conversion to hydrogen by heat-shock digested sludge. Int $J$ Hydrogen Energy. 2003; 28(12): 1361-67.

Laufenberg G, Kunz B, Nystroem M. Transformation of vegetable waste into value added products: (A) the upgrading concept; (B) practical implementations. Bioresource Technol. 2003; 87(2): 167-198.

Machin, D. El uso potencial del ensilaje para la producción animal en la zona tropical, especialmente como una opción para los pequeños campesinos. En: Memorias de la Conferencia Electrónica de la FAO sobre el Ensilaje en los Trópicos. Estudios de la FAO Producción y Protección Vegetal. Roma Italia. 2000; 161, p 73-85.

McDonald P, Henderson AR, Heron SJE. The Biochemistry of Silage. $2^{\text {nd }}$ ed. Kingston, Kent: Chalcombe Publications; 1991.

Moravcová J, Kleinová T, Loučka R, Tyrolová I, Kvasnička F, Dušek M, et al. Coumestrol content of alfalfa following ensilage. Anim Feed Sci Tech. 2004; 115(1-2): 159-167.

Murphy PT, Moore KJ, Richard TL, Bern CJ. Enzyme enhanced solid-state fermentation of kenaf core fiber for storage and pretreatment. Bioresource Technol. 2007; 98(16): 3106-11.

Okine A, Hanada M, Aibibula Y, Okamoto M. (2005). Ensiling of potato pulp with or without bacterial inoculants and its effect on fermentation quality, nutrient composition and nutritive value. Anim Feed Sci Tech. 2005; 121(3-4): 329-343.

Ottati M, Gutierrez M, Bello R. Estudio sobre la Elaboración de ensilado microbiano a partir de pescado proveniente de especies subutilizadas. Arch Latinoam Nutr. 1990; 40(3): 409-410.

Oude, S. (2000). Los Procesos de fermentación del ensilaje y su manipulación. En: Memorias de la Conferencia Electrónica de la FAO sobre el Ensilaje en los Trópicos. Estudios de la FAO Producción y Protección Vegetal. Roma Italia. 2000; 161, p 17-31.

Roberts CA. Microbiology of stored forages. In: Moore KJ, Peterson MA. Editors. Post-Harvest Physiology and Preservation of Forages. Madison, WI. CSSAASA; 1998. p. 21-38.

Parin M. Zugarramurdi A. Aspectos económicos del procesamiento y uso de ensilados de pescado. En: Figueroa V, Sánchez M. Editores. Tratamiento y utilización de residuos de origen animal, pesquero y alimenticio en la alimentación animal. La Habana. Estudio FAO Producción y Sanidad Animal. 1997; No134. p 41-63

Pearson D. Técnicas de Laboratorio para Análisis de Alimentos. $1^{\text {st }}$ ed. Zaragoza, Edit. Acribia S.A.; 1976.
Pizardi C. Producción piloto de hidrolizado de residuos de pescado por fermentación de sustratos sólidos con hongos filamentosos. En: Anales científicos Universidad Agraria La Molina, Lima, Perú. Red Panamericana de Manejo Ambiental de Resíduos (REPAMAR) Centro Panamericano de Ingeniería Sanitaria y Ciencias del Ambiente (CEPIS) 1999. p 122

Plascencia M, Olvera MA, Arredondo JL, Hall GM, Shirai K. Feasibility of fishmeal replacement by shrimp-head silage protein hydrolysate in Nile tilapia (Oreochromis niloticus L.) diets. J Sci Food Agr. 2002; 82(7):753-9.

Seglar B. Fermentation Analysis and Silage Quality Testing. In Proceeding: Minnesota Dairy Health Conference College of Veterinary Medicine; Global Agronomy and Nutritional Sciences. Minnesota, USA. 2003. p 119-123.

Titterton, M. Uso del ensilaje en el trópico privilegiando opciones para pequeños campesinos: Ensilaje de gramíneas y leguminosas en los Trópicos. En: Memorias de la Conferencia Electrónica de la FAO sobre el Ensilaje en los Trópicos. Estudios de la FAO Producción y Protección Vegetal. Roma Italia. 2000; 161, p 43-51.

Vidoiti RM, Dalton JC, Macedo EM. Acid and fermented silage characterization and determination of apparent digestibility coefficient of crude protein por Pacu Piaractus mesopotamicus. J World Aqua. Soc. 2002; 33(1): 57-62.

Vignolo G, Cozzi J, Cortamira O. Fermentación láctica como medio de conservación de residuos de faena de cerdos. La Alimentación Latinoamericana. 2005; 256: 70-3.

Wang HT, Nie YF. Municipal solid waste characteristics and management in China. J Air Waste Manag Assoc. 2001; 51(2): 251-272.

Westerman PW, Bicudo JR. Management considerations for organic waste use in agriculture. Bioresource Technol. 2005; 96(2): 215-221.

Winters AL, Cockburn JE, Dhanoa MS, Merry RJ. Effects of lactic acid bacteria in inoculants on changes in amino acid composition during ensilage of sterile and nonsterile ryegrass. J Appl Microbiol. 2000; 89(3): 442-451.

Yang SY, Ji KS, Baik YH, Kwak WS, McCaskey TA. Lactic acid fermentation of food waste for swine feed. Bioresource Technol. 2006; 97(15): 1858-1864.

Received: November 08, 2010; Revised: January 20, 2011; Accepted: November 26, 2011. 